Akçin, M.E. ve Zengin, O. (2020). Düzensizliğin düzeni: kaos kuramı ve sosyal hizmet. Toplum ve Sosyal Hizmet, 31(3), 1307-1323.

Derleme

Makale Geliş Tarihi: 11.03.2020

Makale Kabul Tarihi: 08.06.2020

\title{
DÜZENSİZLİ̆́iN DÜZENİ: KAOS KURAMI VE SOSYAL HİZMET
}

\author{
The Order of the Disorder: Chaos Theory and Social Work
}

\author{
Mustafa Emin AKÇíN* \\ Oğuzhan ZENGİ***
}

* Yüksek Lisans Öğrencisi, Karabük Üniversitesi Lisansüstü Eğitim Enstitüsü Sosyal Hizmet Anabilim Dalı, mstfkcnn@gmail.com, ORCID: 0000-0002-7750-3138

** Doç. Dr., Karabük Üniversitesi İktisadi ve İdari Bilimler Fakültesi Sosyal Hizmet Bölümü, oguzhanzengin@karabuk.edu.tr, ORCID: 0000-0002-2682-0870

\section{ÖZET}

İçinde bulunduğumuz yüzyılın bilim dünyasını derinden etkileyen kaos kuramı, son zamanlarda sosyal bilimlerde daha çok kullanılmaya ve konuşulmaya başlanmıştır. Bu makale kaos kuramının, sosyal hizmet disiplininin uygulama sürecinde kullanılabilirliğini ele almaktadır. Kaos kuramı, bilim dünyasına yeni bir bakış açısı kazandırarak bir değişime yol açmakla kalmamış aynı zamanda bilim dünyasında disiplinler arası bütüncül bir bakış açısını hâkim kılmıştır. Kaos kuramı, düzensizliğin içinde var olan düzene değinirken, küçük görünen başlangıç koşullarının büyük sonuçları olabileceğini söyler. Geçmişi, insanın var oluşuna kadar dayanan ancak bilimselleşme süreci sosyal bilimler alanında diğerlerine göre kıyasla yeni olan sosyal hizmet disiplini açısından, kaos kuramının beraberinde getirdiği bütüncül bakış açısının ışığında toplumsal hayatta yaşanan kaosların düzenli, adaletli ve insancıl hale dönüşmesi önem arz etmektedir. Karmaşık sistemlerle her alanda ve her düzeyde çalışan sosyal hizmet uzmanları için kaos kuramının kullanılması, sosyal hizmet disiplinin kavramsal çerçevesi bakımından önemlidir. Bu nedenle çalışmada, kaos kuramı ve sosyal hizmet disiplini arasındaki ilişki ortaya çıkarılmış ve sosyal hizmet alanında kaos kuramının kullanımı örneklendirilmiştir.

Anahtar Kelimeler: Kaos kuramı, sosyal bilimler, sosyal hizmet

\section{ABSTRACT}

The chaos theory, which deeply influenced the scientific world of the century we live, has started to be used and spoken more recently in social sciences. This article discusses the practicality of the chaos theory that increases its popularity in the social sciences in terms of the application process of the discipline of social work. Chaos theory not only brought a new perspective to the scientific world and led to a change, but also a holistic interdisciplinary 
perspective in the scientific world. Chaos theory refers to the order within the disorder but says that the initial conditions that appear small may have great consequences. From the standpoint of social work discipline, whose history dates back to the existence of man, but the process of scientificization is relatively new in the field of social sciences, it is important to use the holistic perspective for regular, fair and humane transformation of the chaos experienced in the society. The use of chaos theory for the social workers working with complex systems at all levels, it is important in terms of the conceptual framework of social work discipline. For this reason, the relationship between chaos theory and social work discipline is revealed and the use of chaos theory in social work is exemplified.

Key words: Chaos theory, social sciences, social work

\section{Gíriş}

Kaos denildiğinde akla kargaşa, karmaşık olaylar, aniden ortaya çıkan olumsuz durumlar gibi uç noktalarda yaşanan doğal veya yapay her türlü olay gelebilmektedir. Sözcük anlamı itibariyle bu tür izler taşısa da kaos kuramı, farklı bir kavramsal çerçeveyi ifade etmektedir. Kaos kuramı, ilk olarak pozitivizme bir eleştiri olarak ortaya çıkmış ve fen bilimleri dünyasında büyük bir değişime neden olmuştur. Sonraları sosyal bilimler alanında çalışan bilim insanlarının da dikkatini çekmeye başlayan bu kuram, günümüzde sosyal hizmet disiplininde de tartışılır hale gelmiştir.

Sosyal hizmet birey, aile ve toplumun sosyal işlevselliğini artırmak için çalışan bir meslektir. Sosyal hizmet, bu amaç için gerektiğinde bireyle çalışarak müdahalelerde bulunurken, yeri geldiğinde toplumsal anlamda refah düzeyini artırmak için politikalar üretmeyi kendine görev edinmiştir. Tanım olarak oldukça geniş bir alanı kapsamakla birlikte aynı zamanda mesleki anlamda da toplumsal refahı amaçlaması, sosyal hizmetin değişen toplumsal dinamiklere ve çağa ayak uydurması gereken bir meslek olduğunu göstermektedir. Sosyal hizmet disiplinin doğası gereği değişim ajanı rolünü üstlenerek, değişimi kendinden başlatması ve dinamizmini koruması gerekmektedir.

Çalışmanın temel amacı, toplumsal refah ve sosyal adalet gibi insani açıdan önemli görevler edinmiş olan sosyal hizmet disiplinin dinamizmine kaos kuramıyla katkı sağlayabilmektir. Bu doğrultuda kaos kuramı ve sosyal hizmet arasındaki bağlam kurulmadan önce, ilk olarak kaos kuramıyla ilgili tartışmalar ele alınmış ve ardından kuramın sosyal hizmetle ilişkisine değinilmiş ve uygulanabilirliği tartışılmıştır.

\section{Kaos Kuramı}

Kaos kuramını anlayabilmek için ilk olarak kaosun sözcük anlamına bakmakta yarar vardır. Kaos, sözlük anlamı olarak "Evrenin düzene girmeden önceki biçimden yoksun, uyumsuz ve karışık durumu" ve "kargaşa" olarak karşımıza çıkmaktadır (Türk 
Dil Kurumu, 2020). Kaos, toplumsal kullanımda genellikle sözlükte ikinci anlamı olarak belirtilen "kargaşa" anlamıyla kullanılmaktadır. Kaos denilince akıllara, karmaşık her türlü toplumsal olay, anarşi, aniden ortaya çıkan olumsuz durumlardan hemen sonra yaşanan telaş, doğal afetler, trafik kazaları, toplumsal ve siyasal olaylar gibi anlamları gelebilmektedir.

"Kozmos" kavramı ise kaos kavramının karşıt anlamlısı olarak "düzen" anlamına gelmektedir. İnanmak istediğimiz ve aslında inanmanın bizi iyi hissettirdiği düzenlilik; tarihsel sürece ve alışkanlıklarımıza uyum sağlayan durumun adıdır. Yani düzensizlik istenmeyen özel bir durumdur ve zaman zaman ortaya çıksa da kendiliğinden tekrar düzen halini alacaktır. Fakat kuram olarak kaos, bu durumu tersine çevirerek aslında kendisinin var olması gerektiğini ve düzenli olan evrenin arka planında var olduğunu söylemektedir. Mitolojiler içinde bulunan kaos kavramına baktığımızda da içinde yaşadığımız "kozmos" öncesi evrenin adlandırımasında kullanıldığını görürüz. Bu, antikçağdan günümüze kadar süre gelen yerleşik bir düşünce sisteminin oluşmasına neden olmuştur. Bu kültür sayesinde günümüzde hala kaotik bir olaydan sonra düzenliliğin geleceği genel olarak kabul görmüş bir düşüncedir (Ural, 2004:1-2). Yani kaos, günümüzden yüzyıllar önce de bugün kullanılmakta olan anlamına yakın bir anlamda kullanılmıştır.

Kaos kuramı ise yine ilk bakışta bize kelime anlamındaki kargaşa ve düzensizlik anlamını yansıtıyor gibi olsa da tam olarak bunu ifade etmez. Kaos kuramı, bilimsel anlamda düzensizliğin içindeki düzenin araştırılması olarak ifade edilebilir (Gürsakal, 2001: 4). Kaos kuramı, önceden kestirilmesi imkânsız, içerisinde kuralsız fakat benzer durumların oluştuğu "düzensizliğin bir düzeni” yani amacı olan bir düzensizliği ifade etmek için kullanılır (Töremen, 2000: 204). Bir başka ifadeyle kaos kuramı, karmaşık sistemleri anlamlandırmayı sağlayan, kavramsal, matematiksel ve geometrik tekniklerden oluşan bir kuramdır (Cambel, 1933: akt: Hudson, 2000: 219). Yani kısaca ifade etmek gerekirse kaos, düzensiz ve öngörülmesinin imkânsız olduğu düşünülen sistemlerin ve davranışların, aslında düzensizliğin, düzenli bir şekilde gerçekleştiğini ifade eden bilimsel bir yaklaşımdır. Günlük yaşamda dikkatimizi hiç çekmeyen, tesadüf eseri gibi görünen ama aslında sistemli bir düzenin parçası olan olaylar, kaosun kanıtı niteliğindedir (Aybala, 2018: 6).

Bilimsel olarak genç bir kuram olan kaos kuramının (Uçar, 2010: 36) ortaya çıkması bilim dünyasında bir paradigma değişimiyle gerçekleşmiştir. 17. ve 18. yüzyıllarda fizik, astronomi ve matematikte bilim dünyasına adını ciddi buluşlarla yazdıran Isaac 
Newton'un çalışmalarıyla gelişen pozitivizm -Newtonculuk ya da klasik bilim olarak bilinen görüş- uzun yıllar bilim dünyasında başat unsur olmuştur. Klasik bilim diye tabir edilen bu bilimsel paradigmaya göre dünyada rastlantıya yer yoktur, bütün parçalar bir makinanın çarkları gibi işlemektedir (Yıldırım, 1992: 105). İşte bu noktada klasik bilime eleştirel bir bakış açışı doğacak ve bilimsel dünyada yeni görüşler filizlenmeye başlayacaktır.

Klasik bilim olarak adlandırdığımız bu bilimsel paradigmaya felsefi açıdan baktığımızda ise, temellerinde determinizm karşımıza çıkmaktadır. Determinizm, bir diğer ifade şekliyle "belirlenimcilik", sistemlerin şu anki durumlarının önceki durumlardan kaynaklandığını söyler. Newton'un bilim dünyasındaki geçerliliği ve genel kabulüyle birlikte, bilimsel dünyada determinist görüş hâkim olmaya başlamıştır. Klasik bilimin penceresinden baktığımızda örneğin, Halley kuyruklu yıldızının ne zaman ortaya çıkacağını öngörmek, güneş tutulmasının ne zaman gerçekleşeceğini ve nereden görünebileceğini kesin sonuçlarla hesaplayabilmek, bilimsel anlamda küçümsenmemesi gereken adımlardır. Fakat determinizmin uygulanabilmesi ve Newton mekaniğinin işleyiş göstermesi için sistemin tam anlamıyla çözümüne ve başlangıç koşullarının açık bir şekilde bilinmesine ihtiyaç duyulmaktadır. Söylerken kulağa kolay gelen bu durumun bilinebilmesi, doğada çoğu sistemde imkansızdır (Karaçay, 2004: 4). Bilim dünyasının bu imkansızlıklarla karşılaşma sıklığının artmasıyla bilim insanları, Newton mekaniğini dolayısıyla determinist görüşü sorgulamaya başlamıştır.

“Kaosun başladığı noktada klasik bilim durur.” James Gleick

Klasik bilim, evren ve evrenle ilgili olayların anlamlandırımasında deney ve uygulamaların kullanılması gerektiği, elde edilen sonuçların kesinlik taşıdığı ve her koşulda geçerlilik gösterdiği bir bilimsel yaklaşım olarak tanımlanabilir. Klasik bilimin bu kesinlik olgusu, modern bilimsel yaklaşımların ortaya çıkışıyla sorgulanmaya başlamıştır (Kuhn, 1996: 10-11: akt: Aybala, 2018: 25). 20. yüzyılda bilim dünyasında gerçekleşen hızlı gelişim, doğanın yasalarını araştıran fizikçileri daha farklı konular üzerine düşünmeye ve araştırmaya sevk etmiştir. Dalgalı denizler, bulutların gökyüzündeki dağıışı, kalbin ve beynin işleyişi gibi doğanın düzensiz ve rastgele yapısı farklı alanlarda çalışan Batılı bilim insanlarını araştırmaya yöneltmiştir. Ekonomistler, hisse bedellerindeki iniş çıkışlara; ekologlar, toplumlardaki değişimleri inceleyerek yıldızların galakside kümelenmesine, şimşeklerin ve bulutların izledikleri yollara dair açıklamalar yapmaya çabalamışlardır (Gleick, 2016: 12). 
Dünyadaki doğal olayları gözlemleyip düşündüğümüzde doğrusallığa dair örneklerle karşılaşmak zordur. Çatlayan topraktan, kırılmış cam parçalarına kadar birçok çatallanmalarla, kırıklı ve karmaşık şekillerle karşılaşırız. Doğanın doğrusallığa olan yabancılığı ortadayken akademik dünyada ve eğitim süreçlerinin birçoğunda, genel olarak doğrusal geometriyi ve doğrusallık varsayımını kullanmaktayız. Örneklendirmek gerekirse Batı bilim dünyasının klasik bilim anlayışı, bilardo masasında üzerinde bulunan bir topun hareketlerini anlamlandırmaya çalışırken, başka bir noktadan esme olasılığı olan rüzgarla ilgilenmez. Klasik veya Newtoncu bilimin gözünden dünyaya baktığımızda küçük etkiler, büyük sonuçlara yol açmazlar. Diğer bir ifadeyle eski bilim anlayışı, birtakım nedenleri diğerlerine göre daha önemli görür. Yeni bilim paradigmasında ise bir nedeni, bir diğer nedenden daha önemli ya da daha önemsiz görmek saçmadır. Bilim dünyasında yavaş yavaş filizlenmeye başlayan bu düşüncelerin ardından bazı bilim insanları zamanla klasik bilimin "doğrusallık" kavramını çok fazla kullandığını ve gerçekliğin tartışılır birçok varsayıma dayandığını gözlemlediler. Son yıllarda fizikçiler, biyologlar, sosyal bilimciler ve bilgisayar mühendisleri, ilgilerini doğrusal olmayan dinamikler olarak da isimlendirilen kaos kuramına yönelttiler. Çünkü kaos kuramı, doğrusal neden-sonuç ilişkilerinden çok daha farklı olarak sistemlere geniş bir bakış açısı sunan ve onların ne şekilde değiştiğini anlamaya çalışan bir kuramdı. Bilimsel dünyada gerçekleşmeye başlayan bu paradigma değişimleri, kaos ve karmaşıklık gibi yeni düşünce sistemleri ortaya çıkarmış ve kaos kuramının ortaya çıkmasına zemin hazırlamıştır (Gürsakal, 2001: 45).

Newtoncu görüşün eleştirilmeye başlandığı 20. yüzyılda, görelilik kuramı ve kuantum fiziği ortaya çıkmıştır. Kuantum fiziği, karmaşık sistemlerin ve kaotik durumların açıklanabilmesi anlamında bilim dünyasında büyük adımlar atmıştır. Kuantumun, atomun yapısını anlayabilmek ve açıklamasını yapabilmek için atom altı parçacıkların hareketlerini hesaplayabilmesi gerekiyordu. Deterministik görüşün uygulanabilmesi için atom altı parçacıklarının nerede, ne zaman, hangi yöne ve hangi hızla hareket ettiklerini bilmek önemliydi. Fakat konumları ve hızlarını aynı anda kestirebilmek mümkün olmadı. Bu duruma karşılık "olasılık" kavramı kullanılmaya başlandı. Atom altı parçacıkların hareketleri, belirli olasılıklarla hesaplandı. Bu durumu, ünlü fizikçi Albert Einstein "Tanrının zar attığına inanmam" diyerek eleştirmiştir. Fakat tahminlerin geçerliliği vardır. Çünkü bu tahminler, bir iki tane parçacık için değil, milyonlarcası için yapılmaktadır. Örnek olarak, bir madeni parayı attığımızda yazı ya da tura gelme olasılığı yarı yarıyadır. Tura gelecektir derseniz ya tahmin gerçekleşecektir ya da 
tamamen geçersiz olacaktır. Fakat 1.000 .000 madeni paranın havaya atılması durumunda 500.000 tura gelecek derseniz, yanılma payınız azalmaktadır (Karaçay, 2004:5). Kısacası kaos kuramı, klasik bilimin deterministik ve doğrusal bakış açısına eleştirel yorumlar getirilmiş, başka bir deyişle "at gözlüğünden kurtulması gerektiği" düşüncesini ortaya çıkarmıştır. Fizik ve matematik gibi fen bilimlerinde başlayıp günümüze kadar süregelen, sırasıyla Newtoncu görüş, görelilik kuramı ve kuantum fiziğiyle devam eden değişim süreci, bilim dünyasında yeni bir bilimsel paradigmanın ve disiplinler arası bütüncül bir bakış açısının gerekliliği düşüncesini geliştirmiştir. Kaos kuramı, bu noktada bütüncül bakış açısıyla ve başlangıç koşulları öngörülmesi zor karmaşık sistemlerin anlaşılmasına yönelik cevaplar vermiş, günümüze yalnızca fen bilimlerinde kullanılan bir kuram olarak değil her disiplinin yararlanacağı bir kuram olarak gelmiştir.

Kaos teorisinin mucidi, bir meteoroloji uzmanı olan Edward Lorenz'dir. Lorenz, eski bir bilgisayarda hava durumunu en basit haliyle grafiğe dökerken çıktılarda sürekli tekrar eden ancak hiçbir zaman aynı tekrarların kesin olmadığı bir örüntü keşfetti. Oluşturduğu grafikte incelemeler yapmaya devam etmekteydi. 1961 yılında yine uzun bir dizeyi incelerken kestirme olsun diye baştan sona kaydı incelemek yerine ortadaki bir değeri, başlangıç değer olarak bilgisayara girdi. Örnek olarak 0,506921 sayısıyla hesaplama başladı ve başlangıç değerini 0,506 olarak değiştirdi. Matematiksel olarak çok küçük olan bu değişiklik, bir süre sonra diziyi incelediğinde şaşırtıcı bir sonuç olarak karşısına çıkacak ve yeni bir bilimsel görüşün tohumları atılacaktı. Hava durumundaki değişiklikleri belirlemek için oluşturulmuş bu program, başlangıçtaki verinin olası sonucu vermediği ve çok büyük etkileri olduğu varsayımını geliştirmesine olanak sağlamıştır. Bu grafikten yola çıkan Lorenz, periyodik davranmayan fiziksel sistemlerde, öngörülerin olanaksız olduğunu fark etmişti. Denklemler, atmosferi sadece kabaca betimleyen genellemelerden oluşuyordu (Gleick, 2016: 24-27). Lorenz, bu çalışmalar sonucunda "kelebek etkisi" kavramını ortaya atmış ve günümüze kadar bu isimle gelmiştir.

"Kelebek etkisi” ve "başlangıç koşullarına hassas bağımlılık" olarak adlandırılan, “Çin'de bir kelebek kanadını çırpsa, Meksika Körfezi'nde fırtına çıkabilir” şeklinde betimlenen bu durum, önemsiz gibi görünen bir nedenin oldukça önemli sonuçlara yol açabileceğini söyler (Gürsakal, 2001: 5). Sık kullanılan eski bir deyişte şu şekilde anlatılır: 
"Bir çivi kaybolduğu için bir nal kayboldu. Bir nal kaybolduğu için bir at kayboldu. Bir at kaybolduğu için bir atlı kayboldu. Bir atı kaybolduğu için bir haber kayboldu. Bir haber kaybolduğu için bir savaş kaybedildi ve bir savaş kaybedildiği için bir krallık yok oldu."

Herhangi bir olayın kaotik olduğunu kabul etmemiz için ilk olarak, başlangıç koşullarına hassas bir şekilde bağlı olması, aynı zamanda başlangıç koşullarındaki parametrelerin tam olarak bilinememesi gerekmektedir. Örnek olarak yazı-tura için bir madeni paranın havaya atıldığında hangi tarafın geleceğinin bilinememesi, başlangıç koşullarının belirlememesinden kaynaklanır. Yukarıda bahsettiğimiz Lorenz'in çalışması da meteorolojideki başlangıç koşullarının hassas olmasının, öngörülmeyen sonuçlar ortaya çıkarmasına örnektir. Dolasıyla ortada basitleştirilmiş bir sebep-sonuç ilişkisinden çok, tam olarak tayin edilmesi mümkün olmayan sebepler vardır (Ural, 2004: 4). Kaos kuramının temel taşlarından biri "Kelebek Etkisi” kavramına ek olarak diğer önemli kavramları arasında "Çekerler" ve "Fraktal Geometri” bulunur.

\section{Çekerler}

Çekerler, sistemlerin yöneticisidirler. Örnek vermek gerekirse salınım halinde bir sarkacı verebiliriz. Sürtünmeden dolayı sürekli enerji kaybına uğrayan sarkaçta, bütün hareketler hiçbir hareketin bulunmadığı merkeze doğru gerçekleşir. Bu noktaya "denge noktası" adı verilmiştir. Zaman ilerledikçe hareketler, denge noktasına yaklaşacak ve orada son bulacaktır. Yani başlangıç şartı ne olursa olsun, sarkaç nereden başlarsa başlasın, sonuçta sarkaç denge konumuna gelecektir ve denge noktası sarkaç sisteminin çekeridir (Uçar, 2010: 49-51). Çeker, sistemi çeken ve bırakmayan davranış şeklidir. Dinamik bir sistemin zaman içerisinde ilerlerken varacağı son noktadır (Rulge, 1991: 62; akt: Uçar, 2010: 51). Birçok sistemin, çekerler tarafından yönetildiği kabul edilir.

\section{Fraktal Geometri: Kendi Kendine Benzerlik}

Fraktal geometri, ilk olarak 1975 'te matematikçi Beneoit B. Mandelbrot'un yaptığı çalışmalarla ortaya konulmuştur. Mandelbrot 'The Fractal Geometry of Nature' isimli kitabında, Öklid geometrisiyle betimlene gelmiş doğanın, bu betimlemenin dışında fark edilmemiş olan yüzünü açıklamıştır. Mandelbrot'a göre "klasik Öklid geometrisinin şekilleriyle kıyaslandığında, doğadaki şekiller aslında düzensiz ve parçalıdır (Mandelbrot, 1983; akt: Uçar, 2010: 58). Matematikçiler, Mandelbrot'tan önce doğadaki çoğu şeklin açıklanamayacak kadar düzensiz ve karmaşık olduğunu düşünüyorlardı. Mandelbrot'un ortaya koyduğu fraktal geometri ise, matematikçilerin 
bu görüşlerini yanılttı ve dünya ne kadar düzensiz ve karmaşık olarak görünürse görünsün, aslında matematiksel olarak açıklanabileceğini gösterdi. Bu açıdan baktığımızda Mandelbrot'a göre dünya, düzenli bir düzensizlik sergiler (Uçar, 2010: $60)$.

Fraktal geometri sayesinde kendini tekrar eden ve karmaşık görünen sistemleri anlamak mümkün hale gelmeye başlamıştır. Fraktal geometri, cisimlerin sonsuza kadar küçültülmüş hallerinin de kendisine benzerliğini inceleyen bir geometri dalıdır. $\mathrm{Bu}$ sayede, evrende yer alan karmaşık görünen bütün yapılar, daha iyi anlaşılabilmektedir. Fraktallar, evrendeki tuhaf şekilli yapıların birer anlamı olduğunu ortaya koyarlar (Aybala, 2018: 37) Tüm bu tartışmalara dayanarak kaos kuramıyla ilgili şu önermeler geliştirilebilir:

1) Kaos kuramı, evreni ve doğa olaylarını anlamlandırmamıza, doğrusal olmayan yönlerini açıklamamıza yardımcı olur.

2) Kaos kuramı, bütüncül yaklaşımıyla disiplinler arası bir köprü görevi görür.

3) Kaos kuramı, sistemin başlangıç koşullarına hassas bağlılıklarına dikkat çekerek sonuçta büyük farklılıklar yaratabileceğini gösterir.

4) Her ne kadar, doğa bilimlerinden ortaya çıkmış bir kuram olsa da birçok insani sistemin açıklanmasında en iyi çerçeveyi sunan kuramlardan biri olabilir (Rockler, 1991: 60).

\section{Kaos Kuramı ve Sosyal Hizmet}

21. yüzyıl, küreselleşme sürecinin etkisini bütün dünyada göstermeye başladığı bir yüzyıl olmuştur. Gelişen teknolojiyle birlikte iletişimin olanaklarının artması, uluslararası ticaretin büyümesi, dünyanın koca bir köye benzetilmesine neden olmuştur. Günümüzde dünyanın neresinde olursak olalım, bir başka noktasında yaşanan bir gelişmeyi anlık olarak öğrenebiliyor haberdar olabiliyoruz. Bu süreç insanlar, toplumlar ve ülkeler arası etkileşimi artırmış ve etkileşim arttıkça ilişkiler karmaşıklaşmaya başlamıştır. Gelişen teknoloji ve geçen yıllar her şeyi yenilediği ve değiştirdiği gibi insanların yaşam tarzları ve gereksinimleri de değişmeye başlamıştır. Böylelikle sosyal bilimlerde de insanı anlamaya yönelik olarak yeni yöntemler önem kazanmış ve pozitivist görüşün yanında postmodernizm, nicel yöntemin yanında nitel yöntem gelişmeye başlamıştır.

Hızla devam eden bu sürece birey, aile ve toplumların iyi oluşlarıyla ilgilenen sosyal hizmet mesleğinde de birtakım paradigma değişimleri söz konusu olmuştur. Acar ve 
Çamur Duyan (2003)'a göre Abraham Flexner ile başlayan herhangi bir bilimsel paradigmaya dayanmaması nedeniyle sosyal hizmetin bir meslek olup olmadığına ilişkin eleştiriler, Mary Richmond'un sosyal hizmet mesleğini, psikiyatri disiplininin kuram ve kavramlarına dayandırmasıyla aşılmıştır. Böylelikle insanların yaşadıkları sorunları, yaşamlarının önceki dönemlerinde sahip oldukları sorunlu iletişimlere dayandıran psişik determinizm gibi kavramlara sahip psikanalitik kuram, sosyal hizmette başat paradigma haline gelmiştir. Ancak ilerleyen yıllarda insanların yaşadıkları sorunların, yalnızca önceki ilişkilerinden kaynaklanmayabileceği, var olan sosyal sistemlerle sahip oldukları ilişkilerin de sorunların kaynağı olabileceği düşüncesi, sosyal hizmette gelişmeye başlamıştır (Şahin, 2001). Bu gelişmelerde sosyal bilimlerde görülen pozitivizm tartışmalarının sosyal hizmete yansımalarının etkili olduğu da söylenebilir. Her ne kadar Payne (2014)'e göre sosyal hizmet disiplini hala pozitivist bir yönelime sahip olsa da geleneksel sosyal hizmet düşüncesinin "düzen" paradigmasına yönelik postmodern meydan okumalar söz konusudur. Bu meydan okumaların bir sonucu olarak ünümüzde sosyal hizmet mesleği değişimi temsil eden ve kendini değişim ajanı olarak tanımlayan bir meslektir (Akbaş, 2014). Tüm bu gelişmeler sonrasında psikanalitik kuramın yanında sistem yaklaşımı ve ekolojik sistem perspektifi gibi yaklaşımlar, sosyal hizmetin bilgi temelinde yer edinmiştir. Sosyal hizmetin ilgi alanına giren karmaşık olguları daha detaylı bir biçimde anlamak içinse sistem ve ekolojik sistem yaklaşımının kapsamını genişleten ve bu yaklaşımları tamamlayıcı bir perspektif sunan kaos kuramı, sosyal hizmette daha çok tartışılır hale gelmiştir.

Günümüzde kaos kuramı, bütüncül bakış açısına sahip disiplinler arası bir araştırma alanı olarak bilim dünyasında büyük ilgi görmektedir. Fiziğin yanı sıra ekoloji, fizyoloji, biyofizik gibi alanlarda yeni yaklaşımlar üzerinde çalışmalar devam etmektedir (Uçar, 2010: 41-42). Son zamanlarda sosyal bilimler de kaos kuramına ilgi duymaya başlamış, bu alandaki bilim insanları, kendi alanlarında kaos kuramını kullanmaya başlamışlardır. Kaos kuramının sosyal hizmetteki kullanılabilirliğine bakmadan önce, sosyal hizmetin de dahil olduğu sosyal bilimlerde nasıl kullanıldığına ve neler sağladığına bakmak faydalı olacaktır.

Gürsakal'a göre sosyal bilimlerin zorluğu, öznelerinin ve ilişkilerinin karmaşık olmasıdır (2001: 7). Kaos kuramı, temel özellikleri ve kapsamı bakımından sosyal bilimler için ilgi çekici bir çerçeve sunmaktadır. Toplumsal yapıda yaşanan olay ve değişimlerin açıklaması için son derece uygun ilkeler barındırır. Kaos kuramı, karmaşık ilişkiler düzenini açıklarken, karmaşık ilişkilerin sadece kendi iç yapısındaki 
bağımlılıklara değinmekle yetinmez aynı zamanda büyük resmi görmeye olanak sağlar. Düzendışı olasılıkları içermesi, sosyal bilimler için yeni ufuklar sağlamaktadır (Yeşilorman, 2006: 81). Sosyal bilimler alayazanında en çok alıntı yapılan kavramlardan biri, başlangıç koşullarına bağlılıktır. Bazen küçük hatalar, fiziksel bilimlerde sıklıkla gözlenen bir olay olan geri besleme yöntemi ile büyür. Geri besleme yönteminin varlığı, öngörülebilirlik kavramlarına karşı çıkanları destekler niteliktedir. Kaotik yapıları tanımlayabileceğimizi varsaydığımızda bu sistemin modelinin ve biçiminin tahmin edilememesi anlamı gelmez. Yani başlangıç koşullarına duyarlılık sosyal bilimlerin ilgi alanı olan toplumsal sistemlerin öngörülmesini imkânsız olduğunu belirtirken, tahmin edilebilirlik noktasında yardımcı olmaktadır (Hudson, 2000: 221).

Sosyal bilimlerde kaos kuramının uygulama alanlarından birine örnek olarak psikoloji verilebilir. Psikoloji, kaos kuramının önemli uygulama alanlarındandır. Ancak psikoloji alanında yapıımış çalışmaların çoğu, seçilmiş kavramları içermektedir. Örneğin Duke, kelebek etkisini günlük belirli davranışlardaki sorunların kaynaklarının, yalnızca büyük olaylarla sınırlı olmadığı sonucuna varmak için kullanmıştır. Psikoloji gibi alanlarda kaos kuramı, matematiksel ve grafiksel araçlardan ziyade kavramsal ve mecazi kullanımlarını içerir (Hudson, 2000: 225). Bir başka alanla ilgili örnek, kaos kuramının, eğitim kurumlarına yansımaları ile ilgili bir çalışmadır. Akmansoy (2012), "Kaos Teorisi ve Eğitime Yansımaları" adlı çalışmasında, kaos teorisinin eğitim kurumlarındaki yansımalarını incelemiş, kelebek etkisinin eğitim ortamlarında izlerine rastlamıştır. Araştırmanın sonuçlarına göre uzun yıllar devam eden eğitim sürecinin içinde gerçekleşen ufak bir tökezlemenin, ilerleyen yıllarda daha büyük sorunlarla geri dönüşlerinin olabileceği görülmüştür.

Bu noktada kaos kuramı gibi postmodern bir yönelime sahip olan çözüm odaklı kısa terapinin mucidi olan sosyal hizmet uzmanı De Shazer'e değinmek yerinde olacaktır. De Shazer (1991), arzu edilen davranışsal değişimin birden olmayacağını ve küçük değişimlerin, istenen temel değişime giden yolu oluşturduğunu belirtmektedir. De Shazer çözüm odaklı kısa terapi yaklaşımını kullanmaya başladığı ilk çalışmalarında müracaatçılarından seanslar arasında yaşamlarında nelerin daha iyi olduğu hakkında düşünmelerini istemiş, müracaatçıların üçte ikisi bir sonraki seansta yaşadıkları sorunla ilgili ilerleme kat ettiklerini belirtmiş ve kalan üçte birlik kısmın yarısı daha sonra ilk seferde fark etmedikleri ilerlemeler keşfetmişlerdir. Daha sonra randevu almak için kendisini ilk kez arayan müracaatçılara ilk görüşmeye kadar yaşamlarında iyi giden şeyleri düşünmelerini istemiş ve müracaatçılar bu bekleme sürecinde kendilerini daha iyi hissettiklerini ifade etmişlerdir. Bu da De Shazer'a ilk görüşme 
başlamadan önce dahi olumlu değişimlerin meydana gelebileceğini düşündürmüştür (Sklare, 2013: 4). Tüm bu deneyimlerden sonra De Shazer mucize soru tekniğini geliştirmiş ve çözüm odaklı kısa terapide bu tekniği kullanmaya başlamıştır. Bu teknikte müracaatçıdan yaşadığı sorunla ilgili bir mucizenin gerçekleştiğini varsayması ve yaşadığı sorunun çözüldüğünü hayal etmesi istenir (De Jong ve Berg, 2008). Mucize sorusu sorunla baş etmenin önündeki psikolojik engelleri ortadan kaldırabilmektedir (Iveson, 2002: 153). De Shazer'in deneyimlerini ve kullandığı mucize sorusu tekniğini kaos kuramı temelinde düşünürsek olumlu düşünmenin bile sorunun çözümü konusunda bir tür kelebek etkisi yaratacağını görmüş oluruz.

Kaos kuramının, sosyal hizmetin sosyal sistemlere ilişkin bakış açısında önemli birtakım çıkarımları vardır. Bunlardan en dikkat çekeni, sosyal hizmet uygulamalarında tahmin etme (kestirme) işlevinin sorgulanmasıdır. Özellikle planlı müdahale sürecinin ön değerlendirme ve planlama aşamalarında tahminde bulunmanın önemli bir işlevi bulunur. Ancak çalışılan birey, aile ya da sosyal çevre gibi sistemler, karmaşık sistemlerdir. Bu nedenle bir sorunun nedenine ilişkin tahminde bulunmak her zaman kolay olmayabilir (Stevens ve Hasset, 2007: 129; akt: Çelik ve Polat, 2018: 1328).

Kaos kuramının sosyal hizmet uygulamasına neler katabileceğini, ilk olarak doğrusal ve doğrusal olmayan düşünce sistemiyle ardından, kaos kuramının birkaç temel kavramıla kurgusal bir vaka üzerinden değerlendirmek uygun olacaktır. Bu doğrultuda sosyoekonomik durumu yetersiz tek ebeveynli bir aileyi düşünelim. Bir baba ve lise öğrencisi bir çocuktan oluşan bu ailede, baba işsiz olduğu için geçimini sağlayamadığını belirtip nakdi yardım talebiyle bir sosyal hizmet kuruluşuna başvurmuş olsun. Babanın adına "A", çocuğun adına "B" diyelim. Öncelikle vakayı özetleyip sonrasında doğrusal düşünme sistemiyle düşündüğümüzde, sosyal hizmet uzmanı müdahale sürecini planlamadan önce, müdahaleyi şekillendirecek olası düşüncelerin, tahminlerin ve algılama biçimlerinin doğrultusunda gerçekleşmesi olası durumları aktaralım.

Sosyal hizmet uzmanı, babanın talebine karşılık ailenin evine sosyal inceleme yapmaya gitmiş ve babayla görüşme gerçekleştirmiştir. Kiralık bir evde oturan ve işsizlik maaşı alan babanın dört aydır işsiz olduğu, sobalı ve gecekondu türünde bir evde yaşadığı ve okul saatlerinde görüşme yapılmış olmasına rağmen çocuk B'nin evde olduğu görülmüştür. Gerçekleştirilen görüşmede, baba işinden alkol sorunu nedeniyle çıkarıldığını, tekrar çalışma yaşamına dönmek istediğini ve iki aydır iş 
aradığını ifade etmiştir. Bununla birlikte alkol kullanımıyla ilgili sorunlar yaşadığını belirtmiş, tedavi görmek istediğini ancak oğluna bakacak kimse olmadığından dolayı tedavi sürecine başlamakta kararsızlık yaşadığını söylemiştir. Eşinden ayrılmayı kendisinin istemediğini, dört yıl önce boşandıklarını, boşandıktan sonra eşinin bir başkasıyla evlendiğini, başka bir şehre gittiğini, bir daha kendisinden haber alamadığını, oğlunu da aramadığını ve görüşmediklerini belirtmiştir. Sonrasında Çocuk 'B' ile de görüşme yapılmış, B sorulara kaçamak cevaplar vermiştir. Çocuk B'nin bu tutumu sosyal hizmet uzmanı tarafından, iletişime ve iş birliğine kapalı olarak değerlendirilmiştir. Baba $A$, çocuğun okula düzenli devam noktasında sorun yaşadığını, kendisinin çocuğu için elinden geleni yaptığını ve ebeveynlik görevlerini yerine getirdiğini belirtmiştir. Öncelikle vakayı doğrusal düşünce sistemiyle açıklamaya çalışalım.

Problem çözme yaklaşımı, literatürde güçler yerine sorunlara odaklanması nedeniyle bazı yazarlar tarafından şiddetli bir şekilde eleştirilse de (Şahin, 2001), sosyal hizmette 1960'lardan beri güçlü bir biçimde yer almaktadır. Bu yaklaşım problemin kaynağını araştırırken bireyin ruhsal süreçleriyle fazla ilgilenmeyip, bireyin çevresi ile etkileşimde olduğu sistemlerden doğan ilişkilerinde aramaktadır (Danış ve Kara, 2016: 9). Problem çözme yaklaşımını benimsemiş bir sosyal hizmet uzmanı; bireyin ve ailesinin yaşamında aksaklıklar meydana getiren problemlere odaklanacaktır. Bu bağlamda babanın talebi ve işbirlikçi tutumu, yeni bir iş bulmaya ve tedaviye olan istekliliğini dile getirmesi göz önünde bulundurulduğunda, sosyal hizmet uzmanı doğrusal düşünme sistemiyle, ilk olarak babanın temel sorununun alkol kullanımı olduğunu, alkol tedavisi gördüğünde veya farklı desteklerle alkol sorununu çözdüğü takdirde işsizlik durumundan, ailenin ekonomik dezavantajlardan ve babanın yaşadığı bağımlılık sürecinden kurtulabileceğini düşünebilir. Bununla birlikte sosyal hizmet uzmanı, çocuğun annesinden kopması, ailenin dağılmış olması, babanın alkol kullanımı gibi durumların etkisiyle çocuk B'nin psikolojik olarak olumsuz etkilediğini, bu yüzden okula devamında sorunlar yaşadığını düşünebilir. Bu noktada çocuk "B" ile görüşmeler yapılması, sorunlarının anlaşılabilmesi, eğitim öğretim hayatının sürekliliğinin sağlanması gerekli tedbirlerin alınabilmesi için vakayı bir başka birime yönlendirebilir. Ek olarak baba ve çocuk arasındaki iletişimin gözlemlenebilmesi, aile sisteminin incelenebilmesi ve güçlendirilmesi için aile danışmanlığı gerçekleştirebilir. Tüm bu çalışmalar sonucu, babanın alkol tedavisine başlaması ve aileye çocuk "B" adına, baba işe girene kadar nakdi yardım yapılması, çocuk "B" ile ilgili gerekli tedbirlerin alınması uygun görülebilir. Bu düşüncelerin sonucunda babanın alkol 
tedavisinin olumlu yanıt vermesi, bu süreçte nakdi yardımla desteklenmesi sonucunda babanın iş bulabileceği ve ailenin dezavantajı durumundan kurtulacağı sonucuna varılabilir. Doğrusal düşünce sonucu, sosyal hizmet uzmanının olası müdahalesi bu şekilde açıklanabilirken kaos kuramıyla vakaya baktığımızda, sistemler karmaşık, devamlı değişim içinde olan ve anlık yaşanabilen olaylardan etkilendiği için bu tip bir neden-sonuç ilişkisi yetersiz kalacak (Çelik ve Polat, 2018: 1329) ve vakaya yönelik müdahale yetersiz kalabilecektir. Örneğin babanın alkol tedavisine vereceği yanıtın olumlu sonuçları olacağı kesin midir? Baba alkolü bırakmak istediğini belirtmiş olsa da gerçekten bırakmayı istemekte midir, yoksa nakdi yardımın bağlanması için sosyal hizmet uzmanına bu şekilde mi söylemiştir? Babanın işsiz olmasının nedeninin kesin olarak alkol kullanımı olduğu belli midir, yoksa eşinden ayrılmış olması bir tükenmişlik durumu yaratmış, bu yüzden de özgüven kaybı yaşamış ve çalışma isteğini yitirmiş olabilir mi? Doğrusal düşünme yöntemiyle yaklaşıldığında bu ve buna benzer soruların yanıtı daima belirsiz olacaktır. Babanın, alkol kullanımını bırakmasının birçok farklı sonucu olabilir. İşte kaos kuramı, sosyal hizmet uzmanlarına bu tip durumlarda geniş bir çerçeveden vakaya yaklaşmasını ve doğrusal olmayan bir düşünce yöntemiyle düşünmesini tavsiye etmektedir. Aynı şekilde kaos kuramının en popüler kavramı olan "kelebek etkisini" aklımıza getirdiğimizde, başlangıç durumlarına olan hassas bağlılık durumlarını, daha anlaşılır bir ifadeyle; çok önemsiz gibi görülen bazı yaşanmışlıkların, bazı olumsuz durumların etkilerinin tahmin edilmeyecek derecede büyük olabileceği düşünülürse, sosyal hizmet uzmanları hiçbir durumu önemsiz görmeyecek ve her koşulu, müdahalesinde değerlendirecektir.

Yine kaos kuramının varsayımları ile baktığımızda karmaşık sistemlerin aslında birbirlerine benzerlik gösterdiği düşünülebilir. "Fraktal Geometri” başlığı altında kısaca değindiğimiz bu kavramsallaştırmayı vaka üzerinden düşünecek olursak eğer, ailenin yaşadığı sorunların, en temelden yani en büyük görünenden en küçük ayrıntıdaki problemlere kadar birbirlerine benzer nedenlerden kaynaklanıyor olabilir. Farklı farklı görünse de problemlerin aslında birbirlerine benziyor olabileceğini bilmek, sistemi anlamamıza yardımcı olacaktır. Örnek olarak baba A'nın, boşanma sürecinden bu zamana kadar geçen sürede yaşadığı, ardı ardına gelen sorunlar, onun boşanmaya ve evliliğe bakış açısından kaynaklanmış, aile bu nedenle kaotik bir duruma gelmiş olabilir. Baba, boşanmayı bir başarısızlık olarak içsel dünyasında kavramsallaştırmış, sonrasında işinden olmuş ve işsiz olduğu için tekrar özgüven kaybına uğramıştır. Sorun odaklı baş etme stratejileri geliştirememiş ve alkol kullanmaya başlamış, alkole 
olan bağımlılığı onda yeniden bir özgüvensizlik duygusu yaratmış ve kendisini değersiz hissetmeye devam etmiştir. Süreç, bu şekilde birbirine benzer şekilde devam etmiş olabilir. Bu durumda kaos kuramı, bize nakdi yardım ve alkol tedavisine başlanmasının, sisteme bir yarar sağlamayacağını anlamamızda yardımcı olabilir.

Sosyal hizmet uzmanları, kaos kuramı aracılığıyla, doğrusal olmayan düşünce sistemi geliştirip, müracaatçıların sorunlarına ve intiyaçlarına düzensiz yapıları nedeniyle tahmin edilemeyen sonuçlar doğurabileceğini bilerek yaklaşabilirler (Stevens ve Hasset, 2007: 134; akt: Çelik ve Polat, 2018: 1331). Bu vaka üzerinden kaos kuramı çerçevesinde müdahale sürecini oluşturmaya çalıştı̆̆ımızda, öncelikle kaos kuramının sosyal bilimlerdeki kullanım alanlarının oldukça yeni olduğunu belirtmekte yarar vardır. Sosyal hizmet alanında da oldukça yeni olan kaos kuramı sosyal hizmet müdahale süreçlerine, tek başına bir müdahale yöntemi olmaktan ziyade, bir kavramsal çerçeve olarak temellendirebilir. Kaos kuramının temel kavramları, bütün sosyal sistemlerde karşımıza çıkabilmektedir. Vaka özelinde baktığımızda aile sistemi gerek sosyoekonomik yönden gerekse bireylerin günlük yaşantısı açısından dezavantajlı bir durumdadır. Vakanın çözümlenmesinde müracaatçılara müdahale sürecinde aktif bir rol verilmesi, baş etme yöntemlerinin kazandırıması, dezavantajı durumdan güçlenerek çıkılmasını sağlayabilir. Baba ve çocuk özelinde ve aile ile ilgili yapılacak bütün müdahale yöntemleri bütüncül bir yaklaşımla ele alınmasının daha yararlı olacağı düşünülmektedir.

Bununla birlikte unutulmamalıdır ki kaos kuramı genelci sosyal hizmetin her uygulama düzeyi için oldukça işlevsel bakış açıları sunabilmektedir. Her ne kadar bu çalışmada verilen kurgusal vaka daha çok genelci uygulamanın mikro ve mezzo düzeylerine karşılık gelse de kaos kuramı makro düzey uygulamalar için de oldukça işlevseldir. Örneğin yoksulluk alanında çalışan bir sosyal hizmet uzmanı birey ve aile düzeyinde çalışmalar gerçekleştirdiği takdirde sorunun temeline inilemeyeceğinin farkındadır. Birbirini etkileyen karmaşık sistemlerden bahseden kaos kuramına benzer olarak, sosyal hizmet yaşanan sosyal sorunlarda ekonomik, sosyal ve siyasal sistemlerin etkilerine dikkat çeker. Sosyal hizmete göre çalışılan bütün müracaatçı grupların sorunları, sosyal politikaların, ekonomik sistemlerin ve toplumsal koşulların bir ürünüdür. Sosyal hizmet disiplin ve mesleği yaşadıkları sorunların bireylerin kendi yetersizliklerinden kaynaklandığını savunan görüşleri reddederek sosyal sorunların kaynağı olan "düzene" tüm yönleriyle dikkat çekmektedir. Örneğin kaos kuramının iddia ettiği "düzensizliğin düzenini” yoksulluk olgusunda da görmek mümkündür. Kapitalist ekonomik sistem kendi devamlıı̆̆ını sağlamak için düzenli bir şekilde 
yoksul bireylere intiyaç duymakta ve yoksulluğu tekrar tekrar üretmektedir. Bu doğrultuda sosyal hizmet uzmanları sosyal sorunlara kaos kuramı çerçevesinden baktığında, bu sorunlarla yalnızca mikro ve mezzo düzeylerde çalışsa dahi mesleki çalışmalarının makro etkilerinin olabileceğini, makro düzeydeki çalışmalarıyla da mikro ve mezzo değişimler sağlayabileceğini unutmamalı ve bu inançla çalışmalarını gerçekleştirmelidir. Tüm bunlara ek olarak kaos kuramının genelci sosyal hizmet ile pek çok ortak özelliğe sahip olduğunu vurgulamak gerekmektedir. Örneğin kaos kuramının esnek doğası ve sürekli değerlendirme yapma düşüncesi genelci sosyal hizmetin de özellikleri arasında yer almaktadır. Bununla birlikte kaos kuramının sosyal hizmet uygulamasına yönelik en temel sınırlılığı uygulamaya ilişkin bir yol haritası sunmamasıdır. Kaos kuramı bu yönüyle tıpkı sistem kuramı gibi bir müdahale kuramı olmaktan çok olguların daha iyi anlaşılmasına yönelik açıklayıcı bir kuram özelliği sergilemektedir.

\section{SONUÇ}

İnsanı ve toplumu ilgilendiren her türlü olay, devamlı olarak hareket halinde ve değişim içinde görülmektedir. Dinamizmini hiç kaybetmeyen dünyayı, kesin ifadelere sahip kavramlarla anlamlandırmak oldukça zordur (Ural, 2004: 10). Bu noktada sosyal bilimlerin ilgi odağında bulunan, kavramsallaştırıması, deney ve gözlemi yapılması güç olan karmaşık sistemlerin anlamlandırılmasında kaos kuramı devreye girmektedir. Kaos kuramı, düzensiz ve öngörülmesinin imkânsız olduğu düşünülen sistemlerin ve davranışların, aslında düzensizliğin içinde bir düzen olarak bulunduğunu ifade eden ve bu sistemleri anlamakta bize geniş bir bakış açısı sağlayan bir kuramdır.

Kaos kuramının, sosyal bilimler alanındaki birçok sistemi ve sistemler arası ilişkileri açıklayabilme özelliği, karmaşık sistemlerin ve gün geçtikçe daha da karmaşıklaşan toplumsal sistemlerin hepsiyle, her müdahale düzeyinde çalışan sosyal hizmetin de dikkatini çekmiştir. Karmaşık sistemlerin birbirleriyle girdiği etkileşimlere dokunan, aynı zamanda her türlü dezavantajlı, olumsuz ve kaotik durumlarda devreye girme amacı güden sosyal hizmet açısından kaos kuramı oldukça önemlidir. Şüphesiz, sosyal hizmet disiplininde kaos kuramının yeri sadece uygulamada değil, sosyal hizmet eğitim içeriği ve sosyal hizmet araştırmaları için de geçerlidir. Benimsenmiş olan genelci sosyal hizmet anlayışının ve sistem yaklaşımının bütüncül bakış açısına ek olarak kaos kuramının, çerçeveyi daha da genişleterek eğitime yararlı olabileceği düşünülmektedir. 


\section{KAYNAKÇA}

Acar, H. ve Çamur Duyan, G. (2003). Dünya'da Sosyal Hizmet Mesleğinin Ortaya Çıkışı ve Gelişimi. Toplum ve Sosyal Hizmet, 14(1), 1-19.

Akbaş, E. (2014). Sosyal Çalışmada Çağdaş Eleştirel Perspektifler. Ankara: SABEV Yayınları

Akmansoy, V. (2012). Kaos Teorisi ve Eğitime Yansımaları. Mehmet Akif Ersoy Üniversitesi Eğitim Bilimleri Enstitüsü Yüksek Lisans Tezi, Burdur.

Çelik, G. ve Polat, G. (2018). Karmaşıklık Kuramının Uygulamalı Bir Sosyal Bilim Olan Sosyal Hizmete Yansımaları. Insan ve Toplum Bilimleri Araştırmaları Dergisi, 7(2), 1320-1338.

Danış, M. Z. ve Kara, H. Z. (2016). Sosyal Hizmette Problem Çözme Yaklaşımı. The Journal of Academic Social Science Studies, 45, 1-10.

De Jong, P. \& Berg, I. K. (2008). Interviewing for Solutions (3rd ed.). Belmont, CA: Thomson Brooks/Cole.

De Shazer, S. (1991). Putting Difference to Work. New York: W. W. Norton.

Gleick, J. (2016). Kaos. (Çev. İ. A. Demir) İstanbul: ALFA Yayınları.

Gürsakal,

N.

(2001).

Yeni

Bilim.

http://www.academia.edu/download/37299078/YENI BILIM.docx Erişim Tarihi: 07.01.2020

Hudson, C. G. (2000). At the Edge of Chaos: A New Paradigm for Social Work? Journal of Social Work Education, 36(2), 215-230.

Iveson, C. (2002). Solution-focused brief therapy. Advances in Psychiatric Treatment, 8, 149-156.

Karaçay, T. (2004). Determinizm ve Kaos. Mantık, Matematik ve Felsefe II. Ulusal Sempozyumu. 21-24 Eylül 2004, Çanakkale, Türkiye.

Lale, A. (2018). Kaos Teorisi ve Uluslararası Illişkiler: Arap Baharı Örneği. Gazi Üniversitesi Sosyal Bilimler Enstitüsü Yüksek Lisans Tezi, Ankara.

Payne, M. (2014) Modern Social Work Theory, 4th edn. Basingstoke: Palgrave Macmillan.

Rockler, M. J. (1991). Thinking about Chaos: Non-Quantitative Approaches to Teacher Education. Action in Teacher Education, 12(4), 54-63.

Sklare, G. B. (2013). Çözüm Odaklı Kısa Süreli Psikolojik Danışma (4th ed.). (A. Kaya, Çev. Ed.). Ankara: Pegem Akademi. 
Şahin, F. (2001). Sosyal Hizmette Güçler Perspektifi ve Çözüm Odaklı Mülakat. Aile ve Toplum, 1(4), 59-72.

Töremen, F. (2000). Kaos teorisi ve Eğitim Yöneticisinin Rolü. Kuram ve Uygulamada Eğitim Yönetimi, 22, 203-219.

Türk Dil Kurumu. (2020). Kaos. https://sozluk.gov.tr/ Erişim Tarihi: 07.01.2020

Uçar, S. (2010). Kaos Teorisinin Felsefi Özellikleri. İstanbul Üniversitesi Sosyal Bilimler Enstitüsü Yüksek Lisans Tezi, İstanbul.

Ural, Ş. (2005). Kozmozdan kaosa. Mantık, Matematik ve Felsefe II. Ulusal Sempozyumu. 21-24 Eylül 2004, Çanakkale, Türkiye.

Yeşilorman, M. (2006). Kelebek Kanadını Kimden Yana Çırpıyor? Birleştirilmiş Bilimin Kıyısında Kaos ve Sosyal Bilimler. IKÜ Güncesi Fen ve Mühendislik Bilimleri Dergisi, 4(3), 77-86.

Yıldırım, C. (1992). Bilim Tarihi. İstanbul: Remzi Kitabevi. 